\title{
Consolidation of Continuing Education in Unified Health System: Facilities and Difficulties

Anailza de Souza Duarte ${ }^{1}$, Elizabete Gonçalves Magalhães Filha1, Fernanda Maria Silva', Leilany Dantas Varela1, Lívia de Sousa Rodrigues ${ }^{1}$, Moacir Andrade Ribeiro Filho1, Rosa Maria Grangeiro Martins ${ }^{1}$,

Virgínia Karla Pinheiro de Queiroz', Vivianne Coelho Noronha1, Evanira Rodrigues Maia1, Célida Juliana de Oliveira', Maria de Fátima Antero de Sousa Machado1, Jucier Gonçalves Junior ${ }^{2}$

\section{Abstract}

Introduction: In Brazil, the challenge of articulating a quadrilateral picture composed of (1) professional health, (2) teaching, (3) management and (4) social control, involved in the continuing education in health, has been the subject in the discussion for its construction.

Objective: To build a SWOT Matrix identifying strengths and weaknesses for the implementation of a National Policy of Continuing Education in Health Care in local Unified Health System.

Method: This was a qualitative study carried out with an activity that took place in the Professional Masters in Family Health, of the Northeast Family Health Network, at the Universidade Regional do Cariri. Representatives of the quad from Cariri Cearense region were invited to participate in a wheel of conversation.

Results: Strengths and weaknesses, threats and opportunities for the teaching-service rearrangement, as a way of strengthening primary health care, have been identified and described.

Conclusion: The continuing health education gave the tools the professionals need to expand the possibilities of an effective education, as to improve the community conditions.

\section{Introduction}

In Brazil, the challenge of articulating a quadrilateral picture composed of (1) professional health, (2) teaching, (3) management and (4) social
1 Universidade Regional do Cariri (URCA), Crato (CE), Brazil.

2 Universidade Federal do Cariri (UFCA), Barbalha (CE), Brazil.

\section{Contact information:}

\section{Evanira Rodrigues Maia.}

Address: Universidade Regional do Cariri/ Departamento de Enfermagem.

Rua Cel. Antônio Luis, 1.161, Pimenta. Zip Code: 63100-000. Crato (CE), Brazil.

झ evanira.maia@urca.br

Keywords

Education, Continuing; Unified Health System; Family Health Strategy. 
control has been the subject of a discussion that involves the representatives of the quad, who must participate in the construction of the Continuing Health Education in the Unified Health System (SUS, acronym in Portuguese). They might have the attention from the regional site management, as well as from the national and international scenario, in the discussion about formation, in order to implement the Continuing Health Education as an empowering base of health systems and services

In 1990, the Pan American Health Organization (PAHO) highlighted the Continuing Education as a tool with potential to systematize knowledge in a theoretical and methodological perspective, considering the need for programs that would establish the Continuing Education in Health as a precondition for the development and transformation of models of care. Thus, the National Policy of Permanent Education in Health (PNEPS, acronym in Portuguese) is not only a proposal of the Ministry of Health, but also a policy of the SUS. The Ministry of Health suggests the Continuing Health Education as a strategy for the transformation of formation practices, attention, management, policy-making, popular participation and social control in the health sector [1].

The Continuing Health Education is an effective way for improving the SUS workers' skills, as, with this strategy, we can identify problems, reflect on them and propose mechanisms for intervention, which must be put into practice in different scenarios of SUS. It involves the integration between education and work in health, and of personal knowledge and experience; and it also integrates educational institutions, management and health services [2]. Its implementation and strengthening assume new skills, as leadership, decentralized management, self-management, and quality management. This new scenario enables a broad institutional change, providing cultural transformation, according to the new trends, such as desirable management practices, attention and relationships with the assisted population [3].
The initial and continuing formation of health workers and students should come from health practice experiences, aiming to change the practices and bring them closer to the SUS principles.

In national education, curriculum changes were marked by the introduction of the National Educational Bases and Guidelines Law (LDB, acronym in Portuguese) in 1996. In the context of higher education, the Curriculum Guidelines for Undergraduate Health Courses were defined by resolution 3 of the National Council of Education/Board of Higher Education, in 2001 [1]. These guidelines are under extensive review process in the current scenario.

The movements' effervescence indicated the need to approach health and education fields. This is justified when we reorganize health practices, with trained human resources aware of their role in the consolidation of the system and in according to the SUS premises. It seems impossible to imagine this reorganization without simultaneously interference in vocational formation and work [4]. In general, the integration of the everyday professional health services is developed in accordance with the skills and knowledge practices accumulated during vocational formation process and life. This set of accumulated things needs space for analysis and reflection, so that we can articulate the knowledge and renew the coping capacity, when we face increasingly complex situations in work processes, considering the diversity of professions, users of technologies, relations, organization of services and spaces. Selecting strategies and renovated formation models, linked to the working context and to the participants' space of action, tends to decrease the vacuum in the formation of health professionals in this permanent restructuring [4].

The health professionals, teachers or students' care practice should be considered as a process of action-reflection-action, in which everyone who is involved teaches and learns, performing an interaction with specific scenarios of health practices [5].

Policies and proposals for the formation of SUS professionals should integrate training, qualification, 
and development that implement constant strategies and actions of health services practices with research and theoretical reflection practices, both for the staff from universities and those part of management and assistance [6].

Considering the constant health and demographic transitions, and the alteration in population pattern of illness, we observe changes in the profile and health needs, as well in the responses the system gives in such context. To maintain the achieved and the desired progress in health system, it is necessary to develop more efficient and effective actions, which should be placed in continuous education processes in healthcare, so that they would provide workers and managers to build knowledge, using a closer communication and in locus improvement of actions, aiming to have the opportunity to use the acquired knowledge in services, providing to the user better attendance and an access with quality. A Continuing Education in health ensures the construction and the improvement of collective spaces in health care, with a positive impact on labor relations [7].

The contextualization of the assumptions of Continuing Education and the need to support knowledge about the subject prompted the construction of a participatory/constructive dialogue of professional experiences, management and teaching about Continuing Education in health as practice for strengthening the integration of teaching-service-management-community.

We aimed to build a SWOT Matrix identifying strengths and weaknesses for the implementation of a PNEPS in SUS.

\section{Methods}

This was an activity experienced in the Professional Masters in Family Health, of the Northeast Family Health Network, at the Universidade Regional do Cariri (URCA), with a wheel of conversation. Representatives of the quad from Cariri Cearense region were invited to participate in this discussion.
Representatives of higher education institutions of Cariri (CE), responsible for coordinating internships in Primary Health Care, teachers/tutors of higher education institutions, students who were in training field, Primary Health Care professionals who had internship in their workspaces, representative of Ceará Regional Nursing Council, managers and representatives of social control were invited to join the wheel of conversation. Some participants had more than one of the activities listed above. For example, internship supervisors or preceptors also received internships in their field in the Primary Health Care and/or perceived themselves as service users, being able to discuss more than one of the models. Students who participated in the wheel of conversation should share experiences and know the importance of Continuing Education in health for professional development and the consolidation of SUS [8].

The activity took place on 2015, 8th October, in a room used by Professional Masters in Family Health Course of URCA/Campus Pimenta, at Crato city. The wheel of conversation had the participation of 13 stakeholders and was mediated by five students of the Professional Masters in Family Health Course.

First, a dialogue-based explanation of Continuing Education in health theme was carried out, presenting the theory as the main political-pedagogical strategy for the articulation between theory and practice, i.e., teaching to the health service, considering the critical analysis of the social reality, the respect and appreciation of diverse knowledge in the community, the health needs of individuals and populations, the sectoral management, and the social control [8].

At this moment, coordinators, reporters, and participants were presented, and they shared their personal/professionals experiences with Continuing Education in health.

The SWOT Matrix, a widely tool used for strategic planning in the economic/enterprise area, which provides the identification of factors that enhance or 
weaken the collaboration of those involved in both the internal (strengths and weaknesses) and the external (opportunities and threats) environment, was used. With this tool, strategies can be considered to solve the problems, and favorable factors to the enterprise may be potentiated [9].

The SWOT Matrix can be used in several ways by outside facilitators of big business and other branches of activities that wish to plan their actions. It can be used as a self-knowledge tool, or as contextual analysis and a guide to the definition of an action plan. Its use is relatively simple, and the most difficult part is to identify the real strengths and weaknesses, as well as the most advantageous opportunities and the most important threats of the environment analysis [10].

Through the wheel of conversation, with the opinions and knowledge of the participants, we aimed to find the strengths and weaknesses, the threats and the opportunities to rearrange the teachingservice as a means to strengthen Primary Health Care.

In this activity, internal environment was related to higher education institutions, and external environment was related to health services. To identify the factors that help and hinder the integration teaching-service, we asked the teachers and students to identify strengths and weaknesses, and we also asked the health professionals and users/community to identify opportunities and threats.

The information was exposed in piece of papers and fixed in a panel of the SWOT Matrix. They were arranged according to the similarity of ideas and, after, participants discussed them.

The results of this activity were processed by combined analysis, in which the internal conditions were overlapped and compared with the environmental situations, as a means of finding the strengths and weaknesses, and the opportunities and threats [10].

\section{Results}

After the conversation wheel, a panel was built with the obtained information (Table 1).

Table 1. Information of the SWOT Matrix. Crato (CE), Brazil, 2016.

\begin{tabular}{|c|c|c|}
\hline $\begin{array}{l}\text { SWOT } \\
\text { Matrix }\end{array}$ & Factors that help & Factors that hinder \\
\hline \multirow{3}{*}{ 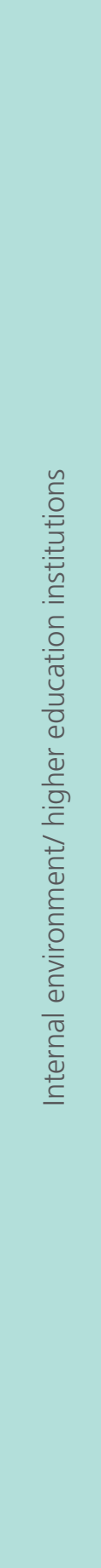 } & Strengths & Weaknesses \\
\hline & $\begin{array}{l}\text { Teachers: } \\
\text { Possibility of } \\
\text { integration and } \\
\text { exchange of } \\
\text { knowledge } \\
\text { Production of } \\
\text { technical-scientific } \\
\text { knowledge, } \\
\text { technical } \\
\text { knowledge, and } \\
\text { practical, critical } \\
\text { and reflexive } \\
\text { knowledge } \\
\text { Exchange of } \\
\text { experience } \\
\text { Real-world } \\
\text { experience } \\
\text { Professional } \\
\text { experience } \\
\text { Problems based on } \\
\text { reality } \\
\text { Link } \\
\text { Partnerships } \\
\text { Students' time } \\
\text { availability for } \\
\text { assignments } \\
\text { Wish to take good } \\
\text { care }\end{array}$ & $\begin{array}{l}\text { Teachers: } \\
\text { Little integration of the } \\
\text { quadrilateral picture; poor } \\
\text { interpersonal relationships } \\
\text { between tutors and } \\
\text { professional service; lack } \\
\text { of dialogue between the } \\
\text { authorities (lack of planning } \\
\text { of internship); service } \\
\text { professionals do not greet } \\
\text { teachers and students } \\
\text { Do not be a member of the } \\
\text { field to be able to interfere } \\
\text { more } \\
\text { Traditional model of } \\
\text { formation, practice almost } \\
\text { always focused on the team, } \\
\text { low participation of users } \\
\text { High demand } \\
\text { Resistance of users } \\
\text { No continuity of care } \\
\text { Bad conditions of health } \\
\text { services, precarious service, } \\
\text { health units/training area } \\
\text { in bad conditions, poor } \\
\text { condition of the internship } \\
\text { space, scarce human and } \\
\text { financial resources } \\
\text { Lack of motivation of } \\
\text { professional service, lack of } \\
\text { professional service support } \\
\text { To realize that there are } \\
\text { students not involved with } \\
\text { the teaching-learning process. }\end{array}$ \\
\hline & $\begin{array}{l}\text { Students: } \\
\text { Humanization } \\
\text { Reception } \\
\text { Exchange of } \\
\text { experience / } \\
\text { knowledge } \\
\text { Evidence-based } \\
\text { therapy }\end{array}$ & $\begin{array}{l}\text { Students: } \\
\text { Lack of team unity } \\
\text { Lack of ethics } \\
\text { No access of user to services } \\
\text { Lack of confidence in the } \\
\text { student } \\
\text { Bad structure } \\
\text { Scarce material resource }\end{array}$ \\
\hline
\end{tabular}




\begin{tabular}{|c|c|c|}
\hline $\begin{array}{l}\text { SWOT } \\
\text { Matrix }\end{array}$ & Factors that help & Factors that hinder \\
\hline \multirow{3}{*}{ 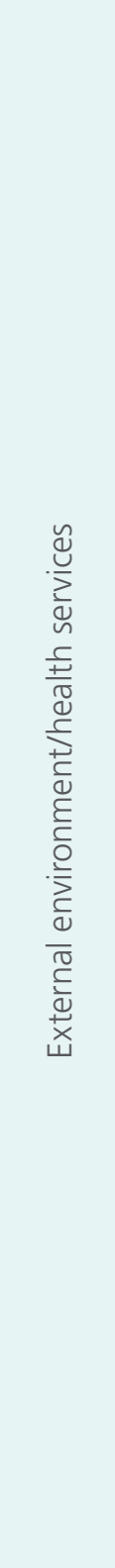 } & Opportunities & Threats \\
\hline & $\begin{array}{l}\text { Health } \\
\text { professionals: } \\
\text { Technical } \\
\text { and scientific } \\
\text { development of the } \\
\text { professional and } \\
\text { the staff } \\
\text { Scientific basis } \\
\text { New experiences } \\
\text { Increase of } \\
\text { new actions } \\
\text { and assistance } \\
\text { methodologies in } \\
\text { service } \\
\text { Learning } \\
\text { Collective and } \\
\text { meaningful learning } \\
\text { Inter-institutional } \\
\text { and inter-sectoral } \\
\text { partnerships } \\
\text { Optimization } \\
\text { of assistance } \\
\text { to be provided/ } \\
\text { improvement of } \\
\text { quality } \\
\text { Improvement of } \\
\text { quality of care } \\
\text { Monitoring of all } \\
\text { actions that must } \\
\text { be developed }\end{array}$ & $\begin{array}{l}\text { Health professionals: } \\
\text { Failure in law related to the } \\
\text { internship } \\
\text { Difficulty in placing students } \\
\text { in the training field } \\
\text { Immaturity of the students } \\
\text { Realizing the little or no } \\
\text { quality of the professionals } \\
\text { Lack of commitment that } \\
\text { can influence preceptors and } \\
\text { students } \\
\text { Lack of temporary "practice" } \\
\text { of students that can cause } \\
\text { conflicts with patients, who } \\
\text { refuse to be attended by } \\
\text { them }\end{array}$ \\
\hline & $\begin{array}{l}\text { Users/community: } \\
\text { To create } \\
\text { opportunities of } \\
\text { learning } \\
\text { Improvement in } \\
\text { attendance. }\end{array}$ & Users/community: \\
\hline
\end{tabular}

\section{Discussion}

The PNEPS emerges as a proposal for a strategic action to contribute to the transformation and the qualification of health practices, the organization of actions and services, the formation processes, and the pedagogical practices in the formation and development of health workers [5,11].

Among the internal factors that help the implementation of Continuing Education practices, tea- chers exposed the technical and scientific knowledge, and the consideration that this knowledge cannot be separated from the practical critical and reflective knowledge, based on reality. We also observed the relevance of professional experience and integration for exchanging knowledge and practice, evidencing the need of the link between formation and establishment of partnerships, so that we can optimize the time and provide care with better quality.

This finding can be justified by the statement of Mitre et al. [12] that claims that education should trigger a vision of the whole, from the search for innovative methods for the formation of man as historical being inserted in the dialectics of actionreflection-action.

In this sense, the formation of professionals for the work that must be developed is highlighted, since the lack of adequate formation, combined with other factors, may result in a sense of professional frustration in the worker [13].

Students considered that internal factors facilitate the Continuing Education with humanization, hosting, exchange of experience/knowledge, and evidence-based therapy.

Internal factors can both facilitate and hinder the educational process. In this perspective, teachers characterized weaknesses as little integration, as well as bad interpersonal relationships between tutors and professional service, which may be the result of the lack of dialogue between the authorities and the lack of planning of internship. Another limitation was the inheritance of the traditional model of formation, with practice almost always focused on the team and little participation of users.

Teachers exposed the difficulties related to the big demand and the users' resistance to be attended by students, and to the no continuity of care. Not being a service member, so that he could interfere, was also another difficulty raised, as well as the poor condition of health services, with limited human and financial resources. The lack of motivation 
and support of professionals, and little involvement of some students in the teaching-learning process, was also observed.

Corroborating these findings and glimpsing the professional role, the need for appreciation emerges, even among team members [14]. The good relationship of the team members, and of those with teachers and students involved in teaching and learning process can produce more satisfactory results, as the articulation of social actors involved in the process creates a favorable environment for the development of good practice, especially the educational one.

In the students' perspective, these difficulties are related to the lack of unity and team ethics, inaccessibility of users to services, lack of confidence in the student, and disability structure and lack of material resources.

The obstacles to the actualization of educational practices produce frustration and loss of sensation in regard to the time spent in attendance and management functions, the inexistence of appropriate physical structure, and the lack of interest of the community and team members [14].

Among the factors related to the external environment, SWOT Matrix presents opportunities and threats. Such factors were related to the environment of health services and reported by health professionals and users/community.

According to health professionals, the opportunities present in the process are related to technical and scientific development of professionals and of the team; to new experiences, the increase of actions and assistance methodologies in service; and to a collective and meaningful learning. Interinstitutional and inter-sectoral partnerships; the optimization of care to be provided with increased quality; and the opportunity of students monitoring all actions that must be developed were also cited. Users/community mentioned the improvement of the service and an appropriate learning as opportunities that should be taken.
Still considering the external environment, here represented by the health services, the SWOT Matrix provides the threats that Continuing Education in health practices can represent. Users/community did not comment this point. Threats were reported by the professionals as failure in law related to the internship; making apparent the little professional quality or no professional quality, because the lack of commitment can influence preceptors and students; the immaturity and no temporary "practice" of students that can cause conflicts with patients, who, in turn, can refuse the attendance by students; and the difficulty of placing the students in internship.

In conclusion, the quadrilateral picture of Continuing Education in health is the basic structure for its consolidation. The strengths and weaknesses for the implementation of a significant health education, as proposed by the PNEPS, include the actors (management, service, education, and user) involved in the process.

The integration of these actors, as well as the relationship of practical critical and reflexive knowledge, based on reality and on the local health needs has fundamental importance for an effective experience in Continuing Education in health. On the other hand, the effectiveness of the role of each component of the quadrilateral, considering the PNEPS, would allow the appreciation of the capacity of health professionals, students and teachers, as well as the development of the potential in each reality, favoring the recovery of the professionals involved in the SUS construction and forming professionals in the SUS and for SUS, to the reality of health.

Thus, the Continuing Education in health as a strategy to instrumentalize health professionals could end the gap caused by the difficulties encountered in its execution, facilitating the teaching-service integration with a strongly consolidated management, with direct participation of social control, expanding the possibilities for an effective education in health, 
and resulting in improving community health conditions.

\section{Authors' contribution}

All the authors equally contributed in all stages of preparation of the article.

\section{Acknowledgments}

To the Brazilian Health Ministry.

\section{References}

1. Brehmer LC, Ramos FR. Experiências de integração ensinoserviço no processo de formação profissional em saúde: revisão integrativa. Rev Eletr Enf [Internet], 2014; 16(1): 228-37.

2. Ceccim RB. Educação permanente em saúde: desafio ambicioso e necessário. Interface: Comunicação, Saúde, Educação. Botucatu, set. 2004/fev. 2005; 9(16): 161-177.

3. Fiúza TM, Ribeiro MT, Gomes KW, Pequeno $\mathrm{ML}$, Barreto $\mathrm{CH}_{\text {, }}$ Miranda AS, et al. Necessidades educacionais dos profissionais da Estratégia Saúde da Família (ESF): possibilidades de Educação em Saúde no município de Fortaleza (CE). Revista Brasileira de Medicina de Família e Comunidade, 2012; 7(24): 139-46.

4. Feurerweker LC. Estratégias atuais para a mudança na graduação das profissões da saúde. Cadernos da ABEM, 2010; 2: 78-80.

5. Gesteirau EC. Aprendizagem prática de graduandos em enfermagem com crianças hospitalizadas. J Nurs UFPE on line, 2013; 7(5): 4572-7.

6. Pereira, JG, Fracolli LA. A contribuição da articulação ensino serviço para a construção da vigilância da saúde: a perspectiva dos docentes. Rev Latino-Am Enferm, 2009; 17(2): 167-73.

7. Pinto TR, Cyrino EG. Listening to the primary health care worker: potential and challenges in educational practices. Interface: Comunicação, Saúde, Educação. Botucatu, 2015; 19 Supl 1: 765-77.

8. Dias MS, Machado MF. (Org.). Caderno do Módulo Educação na Saúde II. Mestrado Profissional em Saúde da Família. Fortaleza; Rede Nordeste de Formação em Saúde da Família; 2015.

9. Ferrell OC, Hartline MD. Estratégias de marketing. 4 ed. São Paulo: Thomson; 2009.

10. Nakagawa M. Ferramenta: Análise SWOT (Clássico). Movimento Empreenda [Internet]. Rio de Janeiro: Globo; 2012.

11. Ceccim RB, Feuerwerker LC. O quadrilátero da formação para a área da saúde: ensino, gestão, atenção e controle social. Physis, Rio de Janeiro, 2004; 14(1): 41-65.
12. Mitre SM. Siqueira-Batista R, Girardi-de-Mendonça JM, MoraisPinto NM, Meirelles CA, Moreira T, et al. Metodologias ativas de ensino-aprendizagem na formação profissional em saúde: debates atuais. Ciên Saúde Coletiva, Rio de Janeiro, 2008; 13(Supl. 2): 2133-44.

13. Trindade LL, Lautert L. Síndrome de Burnout entre os trabalhadores da Estratégia de Saúde da Família. Rev Esc Enferm USP, São Paulo, 2010; 44(2): 274-279.

14. Feliciano KV, Kovacs MH, Sarinho SW. Superposição de atribuições e autonomia técnica entre enfermeiras da Estratégia Saúde da Família. Rev Saúde Pública, São Paulo, 2010; 44(3): 520-7.
Publish in International Archives of Medicine

International Archives of Medicine is an open access journal publishing articles encompassing all aspects of medical science and clinical practice. IAM is considered a megajournal with independent sections on all areas of medicine. IAM is a really international journal with authors and board members from all around the world. The journal is widely indexed and classified Q1 in category Medicine. 